\title{
The use of $\mathrm{CT}$ angiography for preoperative evaluation of large foreign body retention following penetrating trauma
}

\author{
Ugochukwu Ihedioha, ${ }^{1}$ Richard P Stevenson, ${ }^{2}$ Nigel Raby, ${ }^{3}$ David B Kingsmore ${ }^{2}$
}

${ }^{1}$ General Surgery, Northampton General Hospital NHS Trust, Northampton, UK

${ }^{2}$ Vascular, Queen Elizabeth University Hospital, Glasgow, UK ${ }^{3}$ Radiology, Western Infirmary, Glasgow, UK

\section{Correspondence to}

Dr Richard P Stevenson, richardstevenson1@nhs.net

Accepted 28 March 2017

\section{DESCRIPTION}

A 31-year-old man presented to the accident and emergency department with a penetrating injury to his left posterolateral chest wall. He was haemodynamically stable, and there was no significant bleeding from the entry point. Plain anterior radiography (figure 1) of the chest revealed a knife embedded within the extrathoracic tissues extending through the scapula, posterior to the clavicle with the tip lying in the left anterior triangle of the neck.

A CT angiogram with three-dimensional reconstruction was performed, given the proximity to important neurovascular structures. This revealed the anterior edge of the knife was related posteriorly to the subclavian vessels and the tip was entering the carotid sheath. None of the important neurovascular structures appeared to be injured (figures 2 and 3).

Operative exploration was performed with the aim of removing the knife safely. The tip of the knife was identified with no discernible injury to the contents of the carotid sheath. The inferior aspect of the incision was extended laterally to expose the body of the knife and the subclavian vessels.

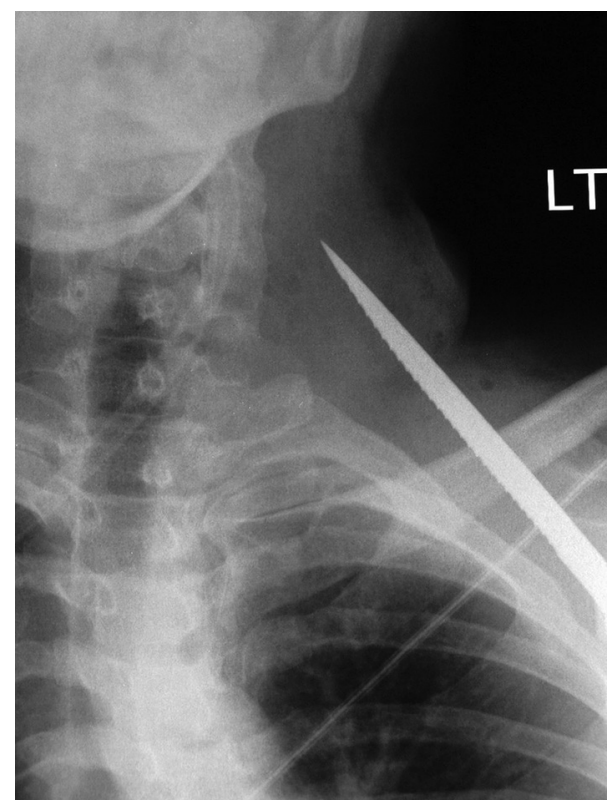

Figure 1 Plain anterior radiograph of the chest revealed a foreign body, with features consistent with a knife embedded within the extrathoracic tissues extending through the scapula, posterior to the clavicle with the tip lying in the left anterior triangle of the neck.

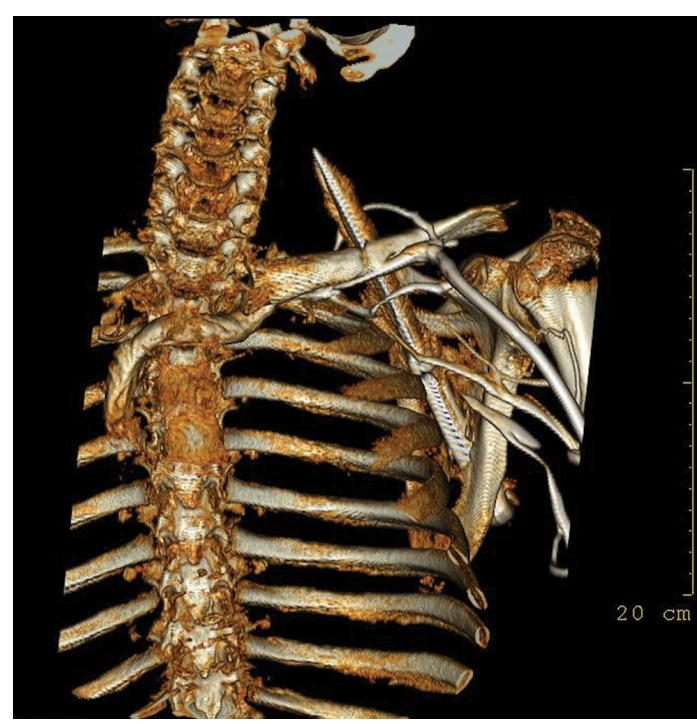

Figure 2 CT angiogram with three-dimensional reconstruction demonstrating the anterior edge of the knife was related posteriorly to the subclavian vessels and the tip was entering the carotid sheath.

Further access was required, therefore a clavicular osteotomy was performed. The knife was found to abut the posterior wall of the subclavian artery but had not penetrated it. The knife was carefully slid

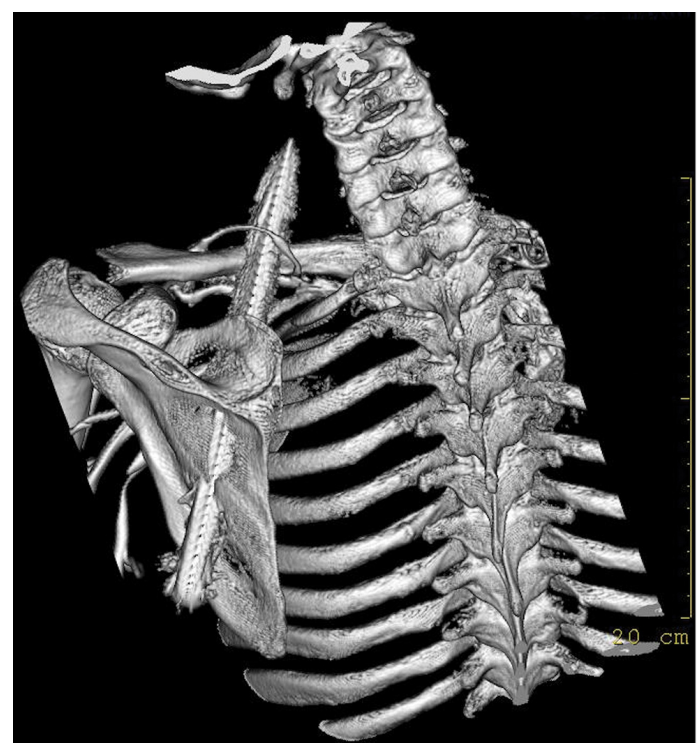

Figure $3 \mathrm{CT}$ angiogram with three-dimensional reconstruction-posterior view. None of the important neurovascular structures appeared to be injured. 


\section{Learning points}

- Penetrating neck injuries account for $5 \%-10 \%$ of all trauma cases presenting to the emergency department with a mortality rate of $3 \%-6 \%$.

- Using anatomical landmarks, the neck is divided into three zones:

Zone 1: Horizontal area between the clavicle/suprasternal notch and the cricoid cartilage encompassing the thoracic outlet structures.

Zone 2: Area between the cricoid cartilage and the angle of the mandible.

Zone 3: Area that lies between the angle of the mandible and the base of the skull.

- Some authors advocate conservative management for stable patients with injuries in any of the zones. ${ }^{23}$ Our patient was stable and had a zone 1 injury; therefore, conservative management would have been ideal. Unfortunately, the knife was embedded which necessitated removal. A form of imaging which could delineate vital structures in this area was therefore useful to guide operative exploration. backwards and removed from the posterior chest wound. The clavicle was plated and the neck wound was closed. The chest wound was left open to allow drainage.

$\mathrm{He}$ was discharged home on day 4. At follow-up, he was asymptomatic and there were no postoperative complications.

Contributors UI was responsible for writing the article and was involved in the management of the patient. RS edited, gained consent and prepared for publication. NR reported the films and reconstructed the CT. DK was the surgeon involved during the operation.

Competing interests None declared.

Patient consent Obtained.

Provenance and peer review Not commissioned; externally peer reviewed.

(c) BMJ Publishing Group Ltd (unless otherwise stated in the text of the article) 2017. All rights reserved. No commercial use is permitted unless otherwise expressly granted.

\section{REFERENCES}

1. Núñez DB, Torres-León M, Múnera F. Vascular injuries of the neck and thoracic inlet: helical CT-angiographic correlation. Radiographics 2004;24:1087-98.

2. Múnera F, Soto JA, Palacio DM, et al. Penetrating neck injuries: helical CT angiography for initial evaluation. Radiology 2002;224:366-72.

3. Demetriades $D$, et al.. Penetrating injuries of the neck in patients in stable condition. Arch Surg 1995; 130:971.

Copyright 2017 BMJ Publishing Group. All rights reserved. For permission to reuse any of this content visit http://group.bmj.com/group/rights-licensing/permissions.

BMJ Case Report Fellows may re-use this article for personal use and teaching without any further permission.

Become a Fellow of BMJ Case Reports today and you can:

- Submit as many cases as you like

- Enjoy fast sympathetic peer review and rapid publication of accepted articles

- Access all the published articles

- Re-use any of the published material for personal use and teaching without further permission

For information on Institutional Fellowships contact consortiasales@bmjgroup.com

Visit casereports.bmj.com for more articles like this and to become a Fellow 